\title{
A Historical Synopsis of some of Mirriam Tlali's Literary Works and Reflections on Black Writing during Apartheid
}

\author{
Dr Theophilus T Mukhuba
}

Senior Lecturer in English Studies, North-West University (Mafikeng campus), Mafikeng, Republic of South Africa

Email:11284722@nwu.ac.za

Doi:10.5901/mjss.2014.v5n20p2432

\begin{abstract}
Mirriam Tlali's produced her most acclaimed literary works during the apartheid era in South Africa. Her literature was defined by, in her own, admission, the desire 'to strike a blow' for the freedom of the enslaved black masses. She achieved her aims by exposing the brutality of the apartheid system in her literary portrayals. This article seeks to contextualise her work within the environment within which it was produced. It also seeks to justify Mirriam Tlali's literature in terms of its relevance for all times. Tlali deliberately chose to write in an 'unconventional' manner, much to the chagrin of writers and literary critics such as Njabulo Ndebele and Lewis Nkosi. These critics charged that Tlali's work was meerly 'sloganeering' and that it was concerned about 'surface symbols'. These critics argue for literature to assume the forms of portrayals simimlar to those of, for instance, the Turkish writer Yasher Kemal. Tlali's literary were produced with a stated aim of 'striking a blow' for freedom' and yet they retain the requisite literary aesthetics.
\end{abstract}

\section{Introduction}

What really inspired protest fiction writings in South Africa during the Apartheid days was the writers' identification with the Black Consciousness ideology and total rejection of the Apartheid regime and its policies. In light of this, perhaps the best way of doing justice to a synopsis of Tlali's work is to delve into the historical background of her work.

South Africa in the 1960's to the early 1990's was glaringly characterized by the ruling white minority's abhorrent institutionalized policy of Apartheid. This policy ensured that the white minority, through systematic brutal oppression and exploitation, held onto social, economic and political power. The powerless and largely voiceless black majority were forcefully relegated to the last rung of the socio-economic and political ladder with very few rights, except perhaps the legal right to be exploited and be oppressed. In the early part of this period, the effective brutality of the apartheid regime's repressive machinery had ensured that black South African lived in a state of perpetual fear and subjugation. Most black leaders who dared challenge the regime's monopoly of power were killed, imprisoned, banned or exiled. The political void left was filled by white liberals who championed the cause of the black man until so-called black liberals began to distance themselves from white liberals and started embracing the black consciousness ideology. Cooper notes that:

This Black Consciousness, as it emerged was no more than one family member 'black liberals' unilaterally declaring independence from the other member 'white liberals' utilizing the language, rhetoric, strategies and tactics of Afro-American political activism (1992:7).

\section{Social Consciousness and Black Consciousness}

The effectiveness of the apartheid state's repressive machinery had ensured that many black people develop an acceptance of themselves as inferior beings compared to whites. Black consciousness adherents set out to correct these stereotypes. They realized that the struggle for black freedom should begin with the freeing of the mental attitudinal perceptions of Blacks. And so began the process of self-identification. Protest fiction, apart from painting a historical picture of the South African way of life, was also used to further black consciousness ideas by conscientizing the people and shocking people into self -awareness. Mutloatse, in explaining what protest fiction does says: ... we are in search of our true selves - undergoing self-discovery as a people (1988:5)

The search for self-definition and self-awareness could not be conducted without drawing the unwanted attention of the state. Despite the brutal repression of the Black Consciousness movement and the ideas it espoused, Black 
Consciousness adherents especially the high priest of this ideology, Steve Biko, pushed on with the re-education of the black person about himself and the redefinition of the political environment. To them it was of fundamental importance to teach blacks to take pride in their humanity, because only then can blacks begin to facilitate the process of undoing the injustices and correcting the imbalances of apartheid. Mosibudi Mangena makes the following assertion:

Black Consciousness as the ethno-political weapon of an oppressed class struggling to reaffirm its humanity through active participation in the demise of a racist and capitalist system. As such, black consciousness was a philosophy of praxis that attempted to eradicate from the black intellect the inculcated submissiveness that contributed to its own enslavement (1991:35).

The enslavement of the black person's mental faculties was a problem and was solely to blame - because he/she allowed it to happen. This was, however, also aided by the fear of the state's security apparatus which penetrated and infringed on every aspect of the black person's life. His life was continually and effectively controlled by the state. In fact, the black person had no personal life. Tlali glaringly portrays this insensitivity of the apartheid regime and how a black person's life was closely monitored better than an experimental laboratory animal in her literary work.

\section{Nature of Tlali's Works}

Tlali's works are grounded in real life experiences. They are also expositions and reflections of her writer's desire and intention to highlight and challenge the absurdities of the apartheid system. Because of her inability, both as a black person and as a woman, to effect meaningful impressions of direct challenge to the apartheid system, she found sanctuary and relief in her writing: writing about her experiences, her anger and resentment towards institutionalized apartheid and her aspirations. Jane Mkhonza, in a review of Muriel at Metropolitan under the headline; 'A book born out of frustration', writes: 'The frustration she suffered in her lifelong desire to become a doctor drove Miriam Tlali into writing her book' (1975:3)

In an interview in which, among other things, Tlali was asked how and why she took to writing, she says:

My life was generally at a low ebb. I would have landed in a mental asylum had I not sat down to write then. The pressure was just unbearable, and writing brought me a great deal of relief, and released some of the anger that was in me... (1993:79)

In response to the question: "So, it was basically your social and political situation that actually motivated you to write", she replies:

Yes, yes, ... the uneasy quiet really made me restless. It was unnaturally quite; we could not hold political meetings, we couldn't speak about any political activities or so on, we couldn't object to the very unpleasant policies of the apartheid system, and that made me really mad (1993:79).

Tlali's writings have been, in general, favourably reviewed in journals and newspapers when they were published. Bearing in mind that much has already been written on Tlali's works from different perspectives, this article intends to add another dimension to the existing research on her works. This dimension is to explore how her life experiences and the historical context in which she found herself reflected on her writings. In so doing the article does not claim originality but hopes to shed some additional light on the writer and her literary works. Although the focus of this article is Tlali and her writings in the context of her life, references shall be made to the broader genre of protest fiction, its detractors and its proponents in an effort to further understand Tlali and the genre within which she operated.

It is worth noting that Tlali's first novel exposes the absurdities of the apartheid system in a subdued manner. In her artistically mature stages one shall see her as a remarkably bold and defiant woman who actually deliberately uses her art as an 'instrument of the struggle'. In a paper presented at a writer's conference in Stockholm she declares the objective of her art:

We who live under the system have to try to overcome the massive pressures, psychological, emotional and spiritual that result from it the committed black writer, whose task is to reflect the day-to-day experiences of the individual is in many instances hampered and even paralysed by the ever-threatening forces around him or her. The black South African writes because there is around him or her (something) that needs to be exposed and expressed. He or she writes to protest, to hit back, to keep pounding at the clamped door until it opens. In times of doubts and uncertainties, people search for the truth in the written word (1988:199).

After her first novel, Muriel at Metropolitan, Tlali's writings assume an overt stance with a political agenda. Her style moves from the conformist form and subdued tone of her first novel to a militant non-conformist style as shown in works 
after Muriel at Metropolitan. In a paper delivered in Amsterdam before the Committee Against Censorship, she clearly states her position and perhaps that of some fellow writers clear in defense of her works against the critics of protest fiction. She defiantly charges that her literary production will not be shaped by critics and their prescriptions.

This is a far cry from the Tlali of the Muriel at Metropolitan days! The tone of this declaration is characteristic of Tlali in her later works such as Amandla and Mihloti. Gone is the subdued, controlled tone and humour. There is a dramatic shift to a Tlali with a mission, a writer determined to use the point of her pen as a spear, a woman motivated by an unquenchable desire to see the despicable system of apartheid overthrown. Her tone now seems to echo an essay title of Charlotte H. Bruner: 'There is no Time in South Africa now for Fairy Stories'. Tlali at this point would probably add, 'there is time only for fighting the regime and conscientizing the people'.

To understand Tlali in her formative years as an aspiring writer one must have a thorough knowledge of the sociopolitical conditions of the years 1969 (when she finished writing her first novel Muriel at Metropolitan) to 1975 (when this novel was finally published after being rejected by some publishers). Most of the literature that captured the essence of this period was banned as Muriel at Metropolitan was.

\section{The Black Experience}

This period was characterised by some resistance to apartheid, particularly by the emergence of the Black Consciousness movement in response to the apartheid regime's intensification of its oppressive programmes. At this point in her life, Miriam Tlali, as a member of the urban black middle class, was largely influenced by Black Consiousness as it appealed to most young educated blacks. Tom Lodge, who, among other things, delineates the history of Black Consciousness in South Africa form the 1960's and 1970;s, makes this assertion about young education blacks in the 1970's:

There is no question... that as far as young urban middle class Africans were concerned, by 1976 the often inchoate philosophy of 'Black Consciousness' was the dominant intellectual influence in their political perceptions (1983:332).

Black writing at this time was rooted in what was known as "the black experience". The phrase "black experience" was coined by Black Consciousness adherents whose central occupation was the issue of self-awareness, of consciousness, an affirmation of 'Blackness'.

Steve Biko, the high priest of Black Consciousness before his death at the hands of the apartheid regime's Security Branch, defines Black Consciousness thus:

Black Consciousness is in essence the realization by the black man (or black woman) of the need to rally together with his brother (and sisters) around the cause of their operation - the blackness of their skin - and to operate as a group in order to rid themselves of the shackles that bind them together to perpetual servitude. It seeks to demonstrate the lie that black is an aberration from the "normal" which is white. It is a manifestation of a new realization that by seeking to ran away from themselves and to emulate the white man, blacks are insulting the intelligence of whoever created them black... It seeks to infuse the black community with a new-found pride in themselves, their efforts, their value systems, their culture, their religion and their outlook on life... (1978:49).

"Black experience" as developed and preached by the Black Consciousness movement was aimed at improving the black person's self-image. It also aimed at disproving the apartheid state's perpetuated idea of the black person as being without a past, a culture and aspirations. Kelwyn Sole comments in this regard: 'The individual black writer is said to partake in "black experience" and "black consciousness" (1988:51). He goes on to quote the playwright Benjy Francis as having written:

Slowly over the years, generations after generations, we became... 'A colonized people i.e. acquiring a new collective consciousness'. This process of conditioning, slow and deathly, blinded us to much in our lives. We see then the process of this acquired collective consciousness (that of the great traditions of the African past) creating a duality which is debilitating ... Latterly, the preoccupation has been the dominance of an African image - a desire of the committed artist to resist imposition and to seek a vital assertion of the inherent collective consciousness (1985:51).

This perception of the black writer and the influence of Black Consciousness on the black writer apply to Miriam Tlali as is particularly evident in her first literary work, Muriel at Metropolitan. One can safely assume, then, that this novel is, besides its biographical content, largely influenced by Black Consciousness thought. It follows then, that one should, in trying to understand certain aspects of Tlali's life and influences, look at Black Consciousness ideas and the socio- 
political environment in which the black writer operates. Gareth Cromwell, in a paper entitled 'Evaluating Protest Fiction (1980)', articulates the nature of black protest writing and also advocates an understanding of this genre. He writes:

Any serious South African writer, but especially one who is not white writes in spite of the punitive sanction of censorship, the arbitrary threat of banning or detention, as well as the indirect pressure of a social, political and economic system "inimical to the realization of cultural aspiration". To write at all under these conditions becomes in effect a challenge to the authority of the state and an act of political subversion (1980:52).

A synopsis of Tlali's writing would not be complete if one does not look at protest fiction as a genre, and its critics. A notable critic of protest fiction, Njabulo Ndebele, makes the following observation on this genre:

In general, writers (of protest fiction) in the cities seem to be clear about one thing: that their writings should show, of themselves and their writings, a commitment to political engagement. According to this view, a poem or a work of fiction should most decidedly be written and be read as offering political insight. It should "strike a blow for freedom" (1991:22).

Kelwyn Sole, as well as Michael Vaughan, reinforces this point on the character of protest fiction by noting in an evaluation of four recent black South African novels:

Each novel can be seen as an expression of this determination (the determination to leave nothing questioned), as part of the struggle of a black South African infused with a sense of political destiny (1988:6).

In a critical analysis of Ndebele's conception of storytelling and fiction in protest writing, Vaugham points out what he thinks Ndebele says about protest fiction and its limitations:

Political commitment comes to mean, broadly condemning apartheid and its agents especially African "sell-outs", and sympathizing with the plight of the majority of the African population, who are victims of this policy. It does not involve a serious analysis of the culture of this "victimised" population; of the themes that resonate in the daily lives of the people. It fails largely to connect with the resonances; to engage with them imaginatively or analytically (1988:188).

Ndebele himself contends that:

One major effect is that the writing's (protest fiction) probing into the South African experience has largely been superficial. This superficiality comes from the tendency to produce fiction that is built around the interaction of surface symbols of the South African reality. These symbols can either be characterised of either good on the one hand and symbols of evil on the other hand (1991:23).

Ndebele's criticism of protest fiction includes writers such as Tlali, Sepamla and others. His own fictional writings are, on the whole, not remarkably different from protest fiction works as is evident particularly when one compares his acclaimed collection of short stories Fools and Other Stories and protest fiction works.

\section{Comparison and Contrast of Stories by Tlali, Ndebele ans Sepamla}

The arguement here is not that Ndebele wants black fiction to be devoid of politics per se. As has been pointed out earlier, one finds his argument to be inappropriate as he himself writes in almost the same vein as those he criticizes. His stories also contain strong political overtones, as do the stories of those he criticizes. Michael Vaughan seems correct when he observes that in Ndebele's critical writing,

We find the presence, or at least the reference to, wider discourses of the local society. The discursive pressure of the African population, the wider society of the disenfranchised, the oppressed, the alienated, the impoverished, but also the combative, the resilient, the resourceful and the inventive (1988:5)

But Vaughan stops short of acknowledging that writers such as Sepamla and Tlali also portray these aspects in their writings. The inference is that it is only Ndebele who capably adapts his works to wider discourses of the local society. This inference can be proven wrong by reference to the works of those that Vaughan criticizes by implication and Ndebele mentions by name. For example, Sipho Sepamla's short strory, 'King Taylor', in the anthology Forced Landing, bears the hallmarks of Ndebele's definition of storytelling and Vaughan's approving observations on Ndebele's writings. 'King Taylor' is a story which Sepamla is particularly proud of as he regards it as the manifestation of his professed literary perception of 'writing about the condition of man'.

The story revolves around a black man called Mandlenkosi Thela, who is forced by the ever-worsening conditions of his existence as a black man to change his name to 'King Taylor' so that he can at least be exempted from some of the many humiliations that are always visited upon him. In a racially fragmented country like South Africa, different races were accorded different status and treatment. The black man was by law, placed at the lowest rung of this social 
hierarchy. As King Taylor, he thinks he will qualify to be accorded the treatment meted out by the system to the so-called coloured, and this is presumably better than being a black man. King Taylor soon realizes that this is not the case, as he continues to receive the short end of a system based on racial division and designed to keep him powerless in every sense and therefore easy to control. He is forced to witness his own degeneration as his life becomes increasingly meaningless. Finally, Taylor summons the last ounce of resistance when he realizes that he is systematically being deprived of his human identity. As Taylor recounts the painful memories of the darkness and futility of his existence, he slowly comes to grips with the man in him.

Interestingly, this is what Ndebele thinks literary fiction should be about: the portrayal of 'interiority' rather than the superficial portrayal of 'exteriority'. Through 'King Taylor', it is almost as if Sepamla duplicates and propagates Ndebele's idea of literary fiction. After the furniture people had repossessed his bedroom suite, Taylor remarks: "People look at you on the outside. In time l've come to know the truth..." (1987:90). This revelation is remarkable for a man who at one stage of his life wanted to gain from the death of his son after a car accident. The attempt to gain from a

tragic occurrence is a reflection of moral depletion and mirrors his own sense of worth. The real man within surfaces with the realization of his worth as a person. He concludes by saying:

... there is a lot that has happening in my mind. You see the 'pass is me. Not the identity. The 'pass' is my skin-top. Yet no one can touch the man underneath the skin. That is him saying: "Go back to Majuba" ... I know it won't be easy "to bring from the dead" Mandlenkosi Thela. And that man has to rise from the grave. And he will (1987:90).

It is quite obvious that in the end Taylor, though still living under the same conditions of 'modern slavery', reawakens to the realization of himself as a man, regardless of his outward circumstances of life. He is therefore cleansed of artificiality and this enables him to shed the spirit of defeatism.

Taylor can be compared to Zamani in Ndebele's 'Fool', who also undergoes a period of moral depletion and lives a hopeless, meaningless life. In both characters there is remarkable growth of perception. In 'Fools', Zamani develops a new awareness of his existence especially after the burly white man lashes at him repeatedly with his whip. He savours a kind of victory that is won without physical force:

The blows stopped; and I knew I had crushed him. I had crushed him with the sheer force of any presence. I was there, and would be there to the end of time; a perpetual symbol of his failure to have a world without me. And he walked towards his car, man without a shadow. The sun couldn't see him. And the sound of his car when he drove away seemed so irrelevant. There he went: a member of a people whose sole gift to the world has been the perfection of hate. And because there was nothing more in them, they will forever destroy, consuming us and themselves in a great fire (1983:276).

Ndebele's power of description is clearly unquestionable, but there is something more to it: the above words by Zamani are a political indictment. In fact, the whole story can be judged to be a political exposition, something that Ndebele goes to great pains to refute as 'unartistic' in literature.

The story also deals as much with the 'exteriority' of the situation as it deals with 'interiority'. As a proponent of the portrayal of 'interiority' in works of fiction, Ndebele over-exerts himself in his criticism. In a paper titled 'The Rediscovery of the Ordinary', in which he states his observations of new writing, a writing that had emerged from the South African townships, Ndebele states:

\footnotetext{
One can come to the conclusion that the conversion of the spectacle has run its course. Its tendency either to devalue or to ignore interiority has placed it firmly in that aspect of South African society that constitutes its fundamental weakness (1986:150).
}

The implication of this statement is that black South African literature, because of its supposed ignorance of 'interiority', relegates itself to mere reportage, because surface reality is presented as it is without the injection of artistic creativity. Ndebele's criticism though often sound, becomes rather confusing as his theory of literature does not apply wholly to his own fictional works. Perhaps the contradictions between his theories and his practical fictional works are deliberate, but he does not let on about this.

What is striking is that the characters in Ndebele's works are presented similarly to those of some of the writers he criticizes. Another example of this is Mojalefa in Miriam Tlali's 'The Point of no Return', also in Forced Landing, who shares the same aspirations and radicalism as Zani in Ndebele's 'Fools'. They both show insight into the plight of the black man and try to change the status quo.

The 'Point of no Return' is a story about Mojalefa and his friends who are about to embark on a defiance campaign against the government of the country. Though there is very little action in the story, a good deal about prevailing 
conditions and the black man's experiences are revealed through the dialogue between Mojalefa and his wife.Mojalefa's wife, like the female characters Ntozakhe and Nosipho in Ndebele's 'Fool', is portrayed as a force of moderation and humanism, typical features in African society. Mojalefa, unlike Zani in 'Fools', is aware of his limitations and his strengths. He acknowledges to Bongi, his wife, that he is only "... a small part of the whole", that the struggle for emancipation must be a concerted effort.

Even though he is just a small part of the whole, he is determined to be part of the sacrifice. He is adamant about his intentions, especially after he has witnessed the apartheid system's cruelty. One instance of this is when his father built a big house and the white superintendent of the township had asked to see it. After he had seen it, the white superintendent said to Mojalefa's father:

\section{"John, you must have spent a lot of money to build and furnish it so well. But, you should have built it on wheels! ... It should have had wheels so that it may move easily" (1987:146).}

This is a reference to the forced removals of blacks from certain areas designated for whites. This experience launches Mojalefa onto a journey of self-discovery. He finds himself and vows to do something about his situation.

One other common aspect in the works of Ndebele and those he criticizes, is the treatment of Christianity. Christianity in the South African situation is portrayed as an inherent ill in society because it is seen to preach obedience and tolerance to oppression.

Mojalefa tells his wife about his father and how his father is disappointed with him. He says:

"You see, as a preacher, he has to stand before a congregation every Sunday and preach on the importance of obedience, of how, as Christians, we have to be submissive and tolerant and respect those who are in authority over us under all conditions. That we should leave it to the hand of God to right all wrongs. As a reprisal against all injustices we must kneel down and pray because as the scriptures tell us, God said: 'Vengeance is Mine' (1987:18).

In 'Fools', Ndebele also seems to hold Christianity in low esteem. It is mocked as much as it is in Tlali's 'Point of no Return'. This can be seen in a letter Ntozokhe wrote to Zani in which she tells him about responsibility and foolishness. She writes:

You cannot convince people of your truths by telling them of their foolishness. Just like the Christian missionaries! They are so convinced of their truths that they have become foolish. (1983:86).

Ndebele continues his attack on the Christian faith by attacking the important pillar of Christianity, Jesus Christ. The character Nosipho in 'Fools' tells Zamani in a conversation that :

If there is one woman I'll never be, it is the woman in the bible who washed Jesus' feet and then dried them with her hair. Nor, if I were a man, would I want to be Jesus either. The world is too big for me to be carrying its sins. Jesus is the greatest sin of self-righteousness the world has ever seen. (1985: 86)

It is also important to note that Ndebele makes little, if any, mention of the fact that the writers mentioned in this article including himself, were influenced by the Black Consciousness Movement - hence the common damnation of Christianity and the political radicalism of characters in their works who are obsessed with grasping their own political destinies.

In an article in which he traces the beginnings of protest literature, Kelwyn Sole writes:

The late 1960's and 1970's saw the articulation of a combative, challenging ideological and political perspective among the radical black intelligentsia in South Africa; the ideology of Black Consciousness. Black Consciousness stressed inter alia the need for black unity in the face of apartheid, the need for political and psychological liberation and self-reliance among black people, a stress on what were conceived of as positive black values, such as a humanistic and communalistic approach to life, and a preoccupation with the rediscovery of black history and culture (1988:66).

Sepamia and Tlali both agree that they write with the intention of projecting all that Sole says. If, in their literature, they write all this, then what does one make of Ndebele's contention that they write their fiction for a white liberal readership and to solicit pity from those liberals?

In a hard-hitting response to attacks like Ndebele's on her works, Tlali, in a speech delivered in Amsterdam, contends:

To the Phillistines, the banners of books, the critics ... We black South African writers (who are faced with the task of conscientising ourselves and our people), are writing for those whom we know are the relevant audience. We are not 
going to write in order to qualify or fit into YOUR definition of what you describe as 'true art'. Our main objective is not to receive ballyhoo comments on our works. What is more important to us is that we should be allowed to reach our audience. Our duty is to write for our people and about them ... We would like to reflect our hopes, desires, sacrifices and endurance in our present in a manner that we know will appeal to them ... (1984:26).

Before Ndebele even ventured to criticize the black writer for his unconventional style of literary art, writers like Mutloatse had already stated their intentions with regard to the method which they will apply in their works. This was a conscious defiance of existing literary conventions with which they were obviously quite familiar. In his introduction to the anthology Forced Landing, Mutloatse (1987) defiantly makes the point that black protest fiction writers will deliberately ignore the so-called 'literary convention' in pursuit to telling their stories their way, critics or no critics.

However, according to Vaughan, Ndebele uses a Western realist tradition of fiction writing. Vaughan defines this concept thus:

Characterised of this Western, realist tradition is its close-up focus on the inner life of the protagonist, a focus which provides the narrative with a significant principle of organisation. What particularly focuses upon in this inner life is the problematic relationship with the world around it. The protagonist, in other words, finds the meaning of life problematic rather than given (1988:191).

It is all very well for Ndebele to try and move black writings towards an already established literary aesthetics or to try and establish a new aesthetics for black literature. But the shortcomings of his efforts are that he is using more or less the same methods in his writing and applying a different critical perspective on black writing. This is inappropriate, especially as this literature is produced and should be judged in a specific historical context in South Africa. In defense of her literary endeavours, Tlali states in an interview:

I see no reason why I should conform my art to anybody's idea of artistic creativity. Anyway, artistic creativity is a relative phrase: it depends who sees what as artistic. You see, as for my work lacking complexity in the form of a multifaceted portrayal of the black person and his or her experiences, I say fine. But my work is clearly rich about a predominant feature of the black person's suffering-imposed pain. For as long as I see pain I shall write about pain (1993).

\section{In Closing}

Perhaps one of the best defences of protest literature is the one advanced by Cecily Lockett in her paper 'The Fabric of Experience: A Critical Perspective on the Writing of Miriam Tlali's Works from a Feminist Perspective'. This paper was published in Clayton's Women and Writing in South Africa. She writes:
Where there has been critical response to her writings, white (and black) critics in South Africa have found her work problematic, and have judged it in terms of inappropriate Anglo-American and European critical paradigms (1989:276).

Ndebele, as is shown here, has adopted this critical stance which Lockett regards to be inappropriate. Ursula A. Barnett displays the same understanding of the nature of Tlali's work in her analysis of Muriel at Metropolitan and Amandla, as Locket does. She writes:

Tlali's method of telling the story is very different... As narrator she is a 'witness to history'. Her authority 'rests on the fact that (she) was present at the critical moment when history took a new turn'. Yet she is not a historian or a reporter (1980:162).

Tlali's literary art is in every respect an art-form informed by the immediacy of a situation. She deliberately flouts the prescriptions of so-called literary conventions in order to reach her intended readership: the oppressed black people of South Africa.

\section{References}

Barnett A 1983. A View of Order: A Study of Black South African Literature in English. London: Sinclair Ltd.

Biko S 1978. I Write What I Like. London: Heinemann Educational Books Ltd.

Clayton C. (ed) 1989.Women and Writing in South Africa. Marshalltown: Heinemann Southern Africa.

Cooper B 1992.To Lay These Secrets Open: Evaluating African Literature. Cape Town: David Phillip.

Cromwell G.Evaluating Protest Fiction', English in Africa, Vol. 7 No. 1, March 1980. 
Lodge T 1983. Black Politics in South Africa Since 1945. Johannesburg: Ravan Press.

Mkhonza J. 'A Book Born out of Frustrtion', The World, November 27, 1975. P3>

Mutloatse M. (ed) 1987. Forced Landing. Braamfontein: Ravan Press.

Ndebele N 1991. Rediscovery of the Ordinary: Essays on South African Literature and Culture. Johannesburg: COSAW.

Sole K.'Culture and Politics and the Black Writer: A Critical Look at Prevailing Assumptions', English in Africa, Vol. 10, No. 1, May 1988.

Sole K.'The Days of Power: Depictions of Politics and Community in Four Resent South African Novels, Research in African Literatures, Vol. 19, No. 1, 1988

Tlali M. Interview with the Writer, 24 October 1993.

Tlali M. 'Remove the Chains: South African Censorship and the Black Writer, Index of Censorship, Vol. 13, No. 2, 1988.

Vaughan M. 'The writer as a Storyteller', African Studies Seminar Paper, March 1988. 